\title{
The Effect of Rhizobacteria in the Reducing drought Stress in Soybean (Glycine max L.)
}

\author{
E. Oral, R. Tunçtürk, M. Tunçtürk
}

10.18805/LR-631

\begin{abstract}
Background:This study was carried out to determine the effects of rhizobacteria and blue green algae applications on some physiological properties of soybean (Glycina max L.) grown under water stress.

Methods: The experiment was conducted in factorial order with 4 replications according to the randomized plot trial design. In the research, Arisoy variety belonging to soybean (Glycine max L.) species was used. In the experiment, it was aimed to examine the effects of three different irrigation levels (100, 50 and 25\%) on some physiological characteristics of soybean with a control (control (B0), two different bacteria used. In this study, strains R1 of Azospirillum lipoferum bacteria, strains numbered 98 belonging to Bacillus megaterium bacteriaein and one blue green algae (Chlorella saccharophilia) were used.

Result: According to the average data obtained, root length is $24.75 \mathrm{~cm}-30.85 \mathrm{~cm}$, seedling length $28.10-36.57 \mathrm{~cm}$, root fresh weight 1.10-1.43 g, seedling wet weight $1.55-2.41 \mathrm{~g}$, root dry weight $0.15-0.18 \mathrm{~g}$, seedling dry weight $0.38-0.46 \mathrm{~g}$, azote balance index $70.64-$ 82.90 (dualex value), flavonol 0.375-0.398 (dualex value) and anthocyanin 0.016-0.045 (dualex value), with water restriction showed a decrease in most of these values. It has been determined that the rhizobacteria and blue-green algae have a decreasing and regulating effect on the physiological properties examined.
\end{abstract}

Key words: Drought stress, Rhizobacteria, Soybean, Tolerance.

\section{INTRODUCTION}

Stress factors are undoubtedly the most important factors limiting plant production in the world and in our country (Samancıoğlu and Yıldırım, 2015). This effect is expected to increase further with global warming (Denby and Gehring, 2005). The most important of these stress factors are; non-biotic stress factors such as drought, salinity, high and low temperature, floods, radiation, pollutants, oxidative stress, wind, lack of nutrients in the soil negatively affect the growth and development of plants (Samancıoğlu and Yıldırım, 2015). The most important stress factor limiting plant growth is drought. The gradual decrease in water resources due to global warming requires new technologies as well as increasing water use efficiency. Efficient and sufficient use of water resources has become the main item of global meetings. It has been reported that in the next 50 years, agricultural production will be greatly affected due to drought. This will cause an increase in the undernourished world population (Vinocur and Altman, 2005). It has been stated that the contraction in agricultural production due to drought stress will cause major problems (Wu and Wang, 2000). In particular, insufficiency in production and consequently in consumption leads to nutrition and health problems (Dalal et al. 2006). Drought stress is one of the major constraints for pulse production which negatively affecting its growth and production. Screening and selection of desirable genotypes for drought tolerance is the first and foremost important step in pulse breeding program (Jincya et al. 2019). It has been stated that drought is the most important factor limiting yield and quality in legume production (Basheer-Salimia et al.
Department of Field Crops, Van Yuzuncu Yll University, Faculty of Agriculture -6500/ Turkey-Van.

Corresponding Author: E. Oral, Department of Field Crops, Van Yuzuncu Yil University, Faculty of Agriculture -6500/ Turkey-Van. Email: eroloral@yyu.edu.tr

How to cite this article: Oral, E., Tunçtürk, R. and Tunçtürk, M. (2021). The Effect of Rhizobacteria in the Reducing drought Stress in Soybean (Glycine max L.). Legume Research. 44(10): 11721178. DOI: 10.18805/LR-631.

Submitted: 18-05-2021 Accepted: 20-07-2021 Online: 03-08-2021

2021). Inexpensive and short-term studies are needed to solve this problem. For this purpose, although the use of stress-resistant varieties and species is widespread, breeding them is difficult and demanding. In this case, bacterial practices that promote quality and yield in regions under drought stress have been used intensively in recent years (Marulanda et al. 2009). In studies conducted on this subject, it was observed that they obtained successful results from bacterial applications against drought stress (Naveed et al. 2014). These types of bacteria are named as "PGPR" that promote plant growth. In addition, in recent studies, single-celled micro algae that can perform photosynthesis living in salt and fresh waters are also used for this purpose. These microalgae, which are used in biofuel production, cosmetics, medicine and food sector, have been used as a regulator of growth and development in soil and plant against stress factors in plant cultivation. These bacteria and microalgae are applied differently to plants. It has been stated that bacteria use some protein 
and carbohydrate derivatives and carbon and nitrogen compounds secreted from the rhizosphere part of the plants as an energy source (Sarma and Saika, 2004). These bacteria convert the nutrients that cannot be taken directly by the plant into useful forms that can be taken (Malua and Vassilev, 2014). In addition, phytohormone biosynthesis provides many benefits to the plant by eliminating stress sources and reducing pathogenic disease sources. According to the results obtained from bacterial applications in arid and semi-arid regions, it has been determined they are beneficial to plants physically, chemically and biologically (Araujo et al. 2005; Bat et al. 2019). In this study, it is aimed to examine the effects of bacteria and microalgae applications, which are increasingly used today, on some growth and development characteristics and physiological characteristics of soy grown under drought stress conditions.

\section{MATERIALS AND METHODS}

This study was carried out in the fully controlled climate of Van Yüzüncü Yll University, Faculty of Agriculture, Department of Field Crops in 2020. The experiment was conducted in factorial order with 4 replications according to the Randomized Plot Trial Pattern. Arisoy soybean variety (Glycine max L.) was used as seed material. In the trial, 4 different rhizobacteria applications (control $\left(B_{0}\right)$, Azospirillum lipoferum $\left(B_{1}\right)(1 \times 106$ $\left.\mathrm{cfu}^{-1} \mathrm{ml}\right)$, Bacillus megaterium $\left(\mathrm{B}_{2}\right)\left(1 \times 105 \mathrm{cfu}^{-1} \mathrm{ml}\right)$ and microalgae (Chlorella saccharophilia) $\left(\mathrm{B}_{3}\right)\left(2 \times 104 \mathrm{cfu}^{-1} \mathrm{ml}\right)$ and three drought levels (normal irrigation $\left(K_{1}\right), 1 / 2$ reduced $\left(K_{2}\right)$ and $3 / 4$ reduced $\left(K_{3}\right)$ were applied. Sterilized seeds were treated in $10 \mathrm{ml}^{-1}$. It dose of Azospirillum lipoferum and Bacillus megaterium rhizobacterium and 5\% Chlorella saccharophila rhizobacterium solution for two hours. Trial 3 Soybean seeds were planted (28.05.2020) in pots with a volume of $2 \mathrm{It}$, consisting of a mixture of peat and soil (1:2). The soil used in pots was analyzed in the Soil Department laboratory of our faculty and it was observed that it has a clay-loam structure, a slightly alkaline reaction and a low level of organic matter lime and salt content. Immediately after planting, $50 \mathrm{cc}$ of pure water was given to each pot. All the pots were given $50 \mathrm{cc}$ of water every other day from October until the $30^{\text {th }}$ day of drought applications. In addition, on the $12^{\text {th }}$ day after planting, rhizobacterium isolates were given once with irrigation water. On the $15^{\text {th }}$ day, basic fertilization (NPK) was applied to all pots. Before the drought practices started, singling was carried out so that one plant would remain in each pot. The nitrogen balance index (NBI), flavonol (Flav) and anthocyanin (Anth) content in the leaves were measured on the leaf in real time and non-destructively with the Dualex scientific + (FORCEA, France) device just before the harvest on the $49^{\text {th }}$ day of the end of the experiment (Bat et al. 2019). Afterwards, the root and stem parts of the harvested plants were separated, after determining the root and stem length, root and stem fresh weight, root and stem dry weight, they were dried for 36 hours in an oven at $70^{\circ} \mathrm{C}$ and then weighed. Statistical analysis of the data obtained was performed using COSTAT
(Version 6.03) packfresh program and multiple comparison tests were performed according to Duncan test (Düzgüneş et al. 1987).

\section{RESULTS AND DISCUSSION Root length (cm)}

According to the data obtained at the end of the study, the effect of drought and rhizobacterium applications on root length in soybeans was found to be statistically significant at the level of $1 \%$, while the effect of drought $\times$ rhizobacteria interaction was statistically significant at the level of $5 \%$. According to the data obtained from the experiment, as a result of drought stress, the longest roots were obtained from $\mathrm{K}_{1}$ application with $30.85 \mathrm{~cm}$ and the lowest root length was obtained from $\mathrm{K}_{2}$ application with $24.75 \mathrm{~cm}$. However, there is no statistical difference between $\mathrm{K}_{2}$ and $\mathrm{K}_{3}$ applications. In this study, it was observed that the root length of soybean decreased against increasing water stress. In a similar study, it was observed that root wet, root dry and root length values of echinacea plant decreased under stress conditions. It is very similar to our results (Bat et al. 2019).

In the study, as a result of rhizobacteria applications, the highest root length value was measured as $29.06 \mathrm{~cm}$ from Chlorella saccharophila, which is a microalga and the lowest value was measured as $25.13 \mathrm{~cm}$ from the control group without bacterial application (Table 1).

According to the data obtained, the highest root length value in drought $\times$ RB interaction on the root length was obtained from $\mathrm{B}_{3}$ (microalgae) applications under normal irrigation conditions with $34.70 \mathrm{~cm}$, while the lowest value was obtained from $23.30 \mathrm{~cm}$ with $1 / 2$ reduced irrigation and Azospirillum lipoferum bacteria applications (Table 1).

When the moisture needed by the plant is sufficient in the soil, the root length develops in a healthy way. In plants, a dynamic root component is considered to be the most important factor protecting against drought stress (Blum, 2009). The effect of drought stress on root length and root dry matter ratio in plants varies depending on the severity and duration of the stress (Abayomi and Abidove, 2009). It has been stated that bacterial inoculation applied to plants grown in arid or semi-arid climates increases water use efficiency (Heidari and Golpayegani, 2012). It has been reported that especially bacteria and microalgae applications increase the root development by producing IAA and improve the water and plant nutrient intake efficiency (Gururani et al. 2013). In a study conducted by Bat et al. (2019), on echinacea, it was stated that bacteria, algae and algae had positive effects on germination, seedling formation and rooting. A strong root system is accepted as an indicator of resistance to drought stress. It has been observed that the effect of rhizobacteria applications on the root length of soybeans under drought stress was found to be positive. In a similar study, as a result of inoculation with $P$. aeruginosa GGRJ21 bacteria in mung bean exposed to water tress; 


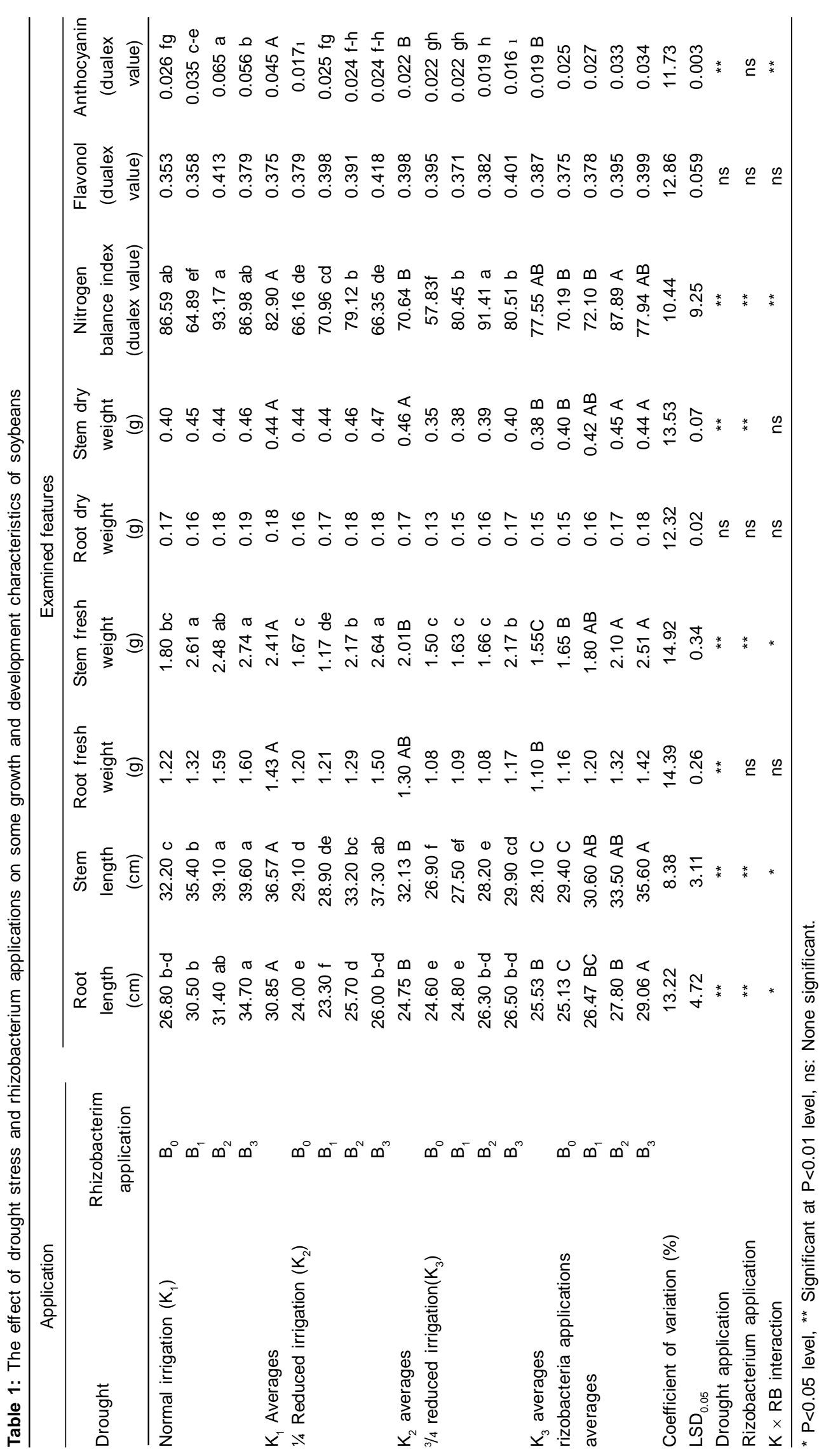


It was determined that the ACC deaminase enzyme activity increased, increasing the root length by $227 \%$ (Sarma and Saikia, 2014).

\section{Stem length $(\mathrm{cm})$}

In the experiment, the effect of drought and rhizobacteria treatments on soybean stem length was found to be statistically significant at the level of $1 \%$, while the statistical effect of $\mathrm{K} \times \mathrm{RB}$ interaction was found to be significant at the level of $5 \%$. In this study, the lowest stem length value obtained from soybean under drought stress with $28.10 \mathrm{~cm}$ was obtained from $3 / 4$ reduced irrigation $\left(\mathrm{K}_{3}\right)$. The highest stem length value was obtained with $36.57 \mathrm{~cm}$ as a result of normal irrigation $\left(\mathrm{K}_{1}\right)$ applications.

As a result of rhizobacteria applications in soybeans, the maximum stem length value was measured as $35.60 \mathrm{~cm}$ from microalgae application and the lowest stem length value was measured as $29.40 \mathrm{~cm}$ in the control group (Table 1).

In the study, the longest value for $\mathrm{K} \times \mathrm{RB}$ interaction on the stem length was determined as $\mathrm{K} 1 \times \mathrm{B} 3$ with $39.60 \mathrm{~cm}$ and the lowest value with $\mathrm{K}_{3} \times \mathrm{B}_{0}$ applications with $26.90 \mathrm{~cm}$ (Table 1).

The reduction in stem length in plants varies depending on the duration of the stress (Bartels and Sunkar, 2005). Although stem growth slows in plants under stress conditions, root growth increases to reach water. As the duration of drought stress increases, root elongation and a consequent decrease in photosynthesis activity occur (Anjum et al. 2011). It has been determined that plants with shorter stem lengths are less affected by drought stress (Shakir et al. 2012). It was found that the application of bacteria such as microalgae in increasing doses contributed positively to the stem length values. It has been reported that commercial biofertilizers containing Azosprillium, Azoarcus and Azorhizobium in wheat increase stem length by $65 \%$ and root length by $29 \%$ (Dal Cortivo et al. 2017). This helps to improve biological characteristics such as root and stem length due to the increase in water use efficiency of plants under drought stress (Bagchi et al. 1990).

\section{Root fresh weight (g)}

While rhizobacteria applications and $\mathrm{K} \times \mathrm{RB}$ interaction on root fresh weight in soybean were found to be statistically insignificant, the effect of drought stress was found to be significant at $1 \%$ level. In this study, according to drought practices, the highest root fresh weight value was determined from $(1.43 \mathrm{~g}) \mathrm{K}_{1}$ and the lowest value was determined from $(1.10 \mathrm{~g}) \mathrm{K}_{3}$ application (Table 1$)$.

It has been observed that drought stress causes significant losses on root fresh weight in plants. In a study investigating the effects of drought stress on root fresh weight in beans; It was determined that $100 \%$ full irrigation in pots, $80 \%$ field capacity and 3 different irrigations at $60 \%$ level decreased by $17,33,55,57,60$ and $52 \%$, respectively, compared to $100 \%$ irrigation level (Kiliçaslan et al. 2020). Depending on the genotype structure of plant species and varieties under drought stress, their response to nutrient intake varies (Sarma and Saikia, 2014). In a similar study, it was stated that depending on the severity of the drought, the plant has an increase in nitrogen intake, a decrease in phosphorus and no effect on potassium. This response varies depending on the plant species and variety (Osakabe et al. 2014).

\section{Stem fresh weight (g)}

According to the data obtained as a result of this study, the effect of drought and rhizobacterium applications on stem fresh weight in soybeans was found to be statistically significant at the level of $1 \%$. The effect of $\mathrm{K} \times \mathrm{RB}$ interaction on stem length was found to be statistically significant at the level of $5 \%$. As seen in $\mathrm{T}$, the lowest stem fresh weight obtained from soybean was obtained from $\mathrm{K}_{3}$ application with $1.55 \mathrm{~g}$. The highest stem fresh weight was measured with $2.41 \mathrm{~g}$ from $\mathrm{K}_{1}$ stress application.

As a result of rhizobacteria applications in soybean, the highest stem fresh weight value was measured as 2.51 $\mathrm{g}$ from $\mathrm{B}_{3}$ application and the lowest value was measured with $1.65 \mathrm{~g}$ in the control group (Table 1).

As a result of this study, $\mathrm{K} \times \mathrm{RB}$ interaction on stem fresh weight was found to be statistically significant. The highest stem fresh weight was determined as $\mathrm{K}_{1} \times \mathrm{B}_{3}$ with 2.74 $\mathrm{g}$ and the lowest value with $\mathrm{K}_{2} \times \mathrm{B}_{1}$ with $1.17 \mathrm{~g}$ (Table 1).

Depending on the severity of the stress, there was a $60 \%$ decrease in stem fresh weight. In a study conducted in peas under watery and dry conditions, significant increases in root and stem weight were found in plants treated with PGPR (Glick, 1995). Plants tend to grow their root parts at the point of reaching water, while shrinkfresh occurs in the above-ground parts in the first phase of drought stress. It has been stated that microalgae, which have recently been used in the world and in our country, are particularly useful in the purification of polluted water resources. Plants have taken more plant nutrients with water and positive results have been obtained in parameters such as stem dry and fresh weight, root dry and fresh weight. In a similar study, in a study examining the effects of drought stress in bean (Phaseolus vulgaris L.) and Sesbania aculeata species under greenhouse conditions, it was found that drought stress decreased in stem fresh weight compared to the control group (Ashraf and Iram, 2005). In a study conducted in melons, it was observed that drought stress decreased the stem weight of the plants by $145.65 \%$. In a study conducted with beans, it was stated that the stem fresh weight decreased by $33 \%$ (Kılıçarslan, 2020). The results obtained are largely similar to our findings.

\section{Root dry weight (g)}

The effects of drought stress on root dry weight of soybeans and $\mathrm{K} \times \mathrm{RB}$ interaction with rhizobacteria were found to be statistically insignificant (Table 1 ). In this study, root dry values varied between $0.15-0.18 \mathrm{~g}$ root dry weight according to drought stress applications (Table 1). 
In a study conducted on beans, a reduction in root dry weight of $52 \%$ was observed in irrigation water at $60 \%$ level of root dry weight compared to $100 \%$ irrigation water (Kılıçarslan, 2020).

\section{Stem dry weight $(\mathbf{g})$}

According to the data obtained at the end of this study, while the effect of drought and rhizobacteria applications on stem dry weight was found to be significant at the level of $1 \%$, the effect of $\mathrm{K} \times \mathrm{RB}$ interaction was found to be statistically insignificant (Table 1). In this study, in terms of drought stress applications, the highest stem dry weight value was obtained from normal irrigation conditions with $0.44 \mathrm{~g}$, while the lowest value was obtained from $\mathrm{K}_{3}$ applications with $0.38 \mathrm{~g}$ (Table 1).

In a study conducted by on melon, it was found that the stem's fresh and dry weight decreased in the first phase of drought stress. It is stated that the root length increases partially. In a study conducted with tomatos, it was stated that the dry weight of the root varied between $49.0-85.6 \%$. It shows a wide variation depending on the severity and duration of the stress. In terms of rhizobacteria applications, the highest stem dry weight was obtained from $B_{2}$ applications with $0.45 \mathrm{~g}$ and the lowest value was obtained from control with 0.40 . It has been observed that bacterial applications have a regulatory and protective effect in reducing drought stress in plants. In a study conducted by Lin and Wu (2014), with buckwheat, it was stated that the application of cyano bacteria reduced the dam fresh caused by drought stress.

\section{Nitrogen balance index (NBI)}

The effect of drought, rhizobacteria and $\mathrm{K} \times \mathrm{RB}$ interaction on $\mathrm{NBI}$ in soybeans was found to be statistically significant at the level of $1 \%$. According to the data obtained from the experiment, as a result of drought stress, the highest NBI value was obtained from $\mathrm{K}_{1}$ application with 82.90 and the lowest NBI was obtained from $\mathrm{K}_{2}$ application with 70.64 (Table 1).

As a result of the application of rhizobacteria, the lowest $\mathrm{NBI}$ value was measured with 70.19 from the control group and the highest value was measured from the $B_{2}$ application 87.89 (Table 1).

According to the data obtained, in terms of nitrogen balance index $(\mathrm{NBI})$, the highest value was obtained from $\mathrm{K}_{1} \times \mathrm{B}_{2}$ interaction with 93.17 in drought $\times$ rhizobacteria interaction, while the lowest value was obtained from $\mathrm{K}_{3} \times$ $\mathrm{B}_{0}$ interaction with 57.83 (Table 1).

In a study conducted with 4 bread and durum wheat under Iranian conditions, it was stated that drought stress at 20, 40 and $60 \%$ decreased nitrogen use efficiency and $\mathrm{NBI}$ values In a study investigating the effects of drought stress on sorghum, it was stated that nitrogen balance in the plant decreased with stress, causing early leaf ripening (Chen et al. 2015). According to these results, it was determined that NBI values decreased depending on the severity of drought stress and bacteria and microalgae applications had a regulatory and balancing effect. Nitrogen balance index can be considered as an important parameter in the growth and development of plants. NBI values can be used to obtain accurate information about yield and quality in crop production. In similar studies, it was observed that $A B I$ values were negatively affected in plants under stress conditions (Lin and Wu, 2014).

\section{Flavonol ratio (dualex value)}

The effect of drought, rhizobacteria and $K \times R B$ interaction on the flavonol ratio in soybean was found to be statistically insignificant (Table 1). In this study, in terms of drought stress, flavonol content varied between 0.375-0.398 dualex value (Table 1).

In parallel with the increasing drought stress, anthocyanin values, a flavonoid compound, decreased in the plant. Anthocyanin, like flavonoid, is a water-soluble compound of various colors. They are found in the spaces in the epidermal and mesophyll tissue of the plant. It creates a secondary defense mechanism in plants by providing color change in various organs against abiotic factors such as drought stress (Bat et al. 2019).

\section{Anthocyanin (dualex value)}

Effect of drought and $\mathrm{K} \times \mathrm{RB}$ interaction on the anthocyanin content in the plants shown in Table 1 was statistically significant at the level of $1 \%$, the effect of rhizobacterium applications was found to be statistically insignificant. According to drought practices, the highest anthocyanin value in soybeans was found to be 0.045 , while the lowest value was found in $\mathrm{K}_{1}$ applications.

Anthocyanin content varies between $0.025-0.034$ values in terms of rhizobacterium applications. In $\mathrm{K} \times \mathrm{RB}$ interaction, the highest anthocyanin value was obtained from $\mathrm{K}_{1} \times \mathrm{B}_{2}$ applications with a dualex value of 0.065 , while the lowest value was obtained from $\mathrm{K}_{3} \times \mathrm{B}_{3}$ applications with a dualex value of 0.016 .

Anthocyanins are low molecular weight polyphenolic compounds found in many plants. They have an important role in flowering in plants. During pollination, they produce red-blue or yellow pigments that attract insect and bee populations (Birman, 2012). In terms of rhizobacterium applications, the flavonol content varied between 0.375 0.399 . Harvesting the plants before flowering is considered as a reason for this situation. In another study conducted with buckwheat, antioxidant activity, polyphenol and flavonoid content increased with the severity of drought stress (Hanson et al. 2011). Rhizobium-bacteria relations in plant breeding are environmentally friendly and have important benefits that increase productivity. In order to reveal this benefit, it is necessary to increase the number of studies with different plants and different rhizobial isolates (Sharma, 2021).

\section{CONCLUSION}

According to the results of the research, while increasing 
drought stress caused a decrease on all traits, increases occurred on all traits examined with rhizobacteria applications. According to the results of the research, it was determined that drought stress had a negative effect on some growth and development parameters and biochemical properties of soy. Bacterial and microalgae applications in soybeans have been found to reduce the harmful effects of drought stress and regulate herbal activity. It has been observed that these properties of bacteria and microalgae contribute significantly to the growth and development of plants. It is thought that conducting similar studies against drought stress, which is a big problem today, will contribute to the literature and the solution of the problem.

\section{REFERENCES}

Abayomi, Y.A., Nodoye, T.O. (2009). Evaluation of cowpea genotypes for soil moisture stress tolerance under screen house conditions. African Journal of Plant Science. 3(10): 229237.

Ashraf, M., Iram, A. (2005). Drought stress induced changes in some organic substances in nodules and other plant parts of two potential legumes differing in salt tolerance. Flora. 200: 535-546.

Anjum, S.A., Xie, X., Wang, L., Saleem, M.F., Man, C., Lei, W. (2011). Morphological, physiological and biochemical responses of plants to drought stres. Afr. J. Agric. Resarches. 6: 20262032.

Araujo, F.F., Henning, A.A., Hungria, M. (2005). Phytohormones and antibiotics produced by Bacillus subtilis and their effects on seed pathogenic fungi and on soybean root development. World Journal of Microbiology and Biotechnology. 21: 1639-1645.

Bartels, D., Sunkar, R. (2005). Drought and salt tolerance in plants. Crit. Rev. Plant Scien. 24: 23-58.

Bagchi, S.N., Palod, A., Chauhan, V.S. (1990). Algicidal properties of a bloomforming blue-green algae, Oscillatoria $\mathrm{sp}$. Journal Basic Microbiology. 30(1): 21-29.

Bat, M., Tunçtürk, R., Tunçtürk, M. (2019). Kuraklık stresi altındaki ekinezya (Echinacea purpurea L.)' da deniz yosununun büyüme parametreleri, topla fenolik ve antioksidan madde üzerine etkisi. Yüzüncü Yıl Üniversitesi Tarım Bilimleri Dergisi. 29(3): 496-505.

Birman, H. (2012). Bitkisel flavonoid bileşiklerinin biyoaktiviteleri ve muhtemel etkisinin mekanizmalari. İstanbul Tıp Fakultesi Dergisi. 1: 73-75.

Blum, A. (2009). Effective use of water (EUW) and not water-use efficiency (WUE) is the target of crop yield improvement under drought stress. Field Crops Research. 112(2-3): 119-123.

Basheer-Salimia, Aloweidat, M.Y., Al-Salimiya, M.A., Hamdan, Y.A.S., Sayara, T.A.S. (2021). Comparative study of five legume species under drought conditions. Legume Research-An International Journal. 44(6): 712-717.

Chen, D., Wang, S., Xiong, B., Cao, B., Deng, X. (2015). Carbon/ nitrogen imbalance associated with drought-induced leaf senescence in Sorghum bicolor. Plos one. 10(8): 1-17.
Dal Cortivo, C., Barion G., Visioli, G., Mattarozzi, M., Mosca, G., Vamerali, T. (2017). Increased root growth and nitrogen accumulation in common wheat following PGPR inoculation: Assessment of plant-microbe interactions by ESEM. Agriculture, Ecosystems and Environment. 247: 396-408.

Dalal, M., Dani, R.G., Kumar, P.A. (2006). Current trends in the genetic engineering of vegetable crops. Scientia Horticulturae. 107: 215-225.

Denby, K., Gehring, C. (2005). Engineering drought and salinity tolerance in plants: Lessons from genome-wide expression profiling in ariadopsis. Trends in Biotechnology. 23(11): 547-552.

Düzgüneş, O., Kesici, T., Kavuncu, O., Gürbüz, F. (1987). Research and Experimental Methods. Statistical Methods-II. Ankara Üniversitesi Ziraat Fakültesi Yayınları 1: 1021-1295.

Glick, B.R. (1995). The enhancement of plant growth by free-living bacteria. Canadian Journal of Microbiology. 41: 109-117.

Grurani, M. A., Upadhyaya, C.P., Strasser, R.J., Yu, J.W., Park S.W. (2013). Evaluation of abiotic stress tolerance in transgenic potato plants with reduced expression of PSII manganese stabilizing protein. Plant Science. 198: 7-16.

Hanson, P, Yang, R.Y., Chang, L.C., Ledesma, L., Ledesma, D. (2011). Carotenoids, vitamin $\mathrm{C}$, minerals and total glucosinolates in choysum (Brassica rapa cv g. parachinensis) and kailaan ( $B$. oleracea Alboglabra group) as affected by variety and fresh and dry season production. Journal Food Compos Anal. 24: 950-62.

Heidari, M., Golpayegani, A. (2012). Effects of water stress and inoculation with plant growth promoting rhizobacteria (PGPR) on antioxidant status and photosynthetic pigments in basil (Ocimum basilicum L.). Journal of the Saudi Society of Agricultural Sciences. 11: 57-61.

Jincya, M., Babu Rajendra Prasad, V., Jeyakumara, P., Senthila, A., Manivannan, N. (2021). Evaluation of green gram genotypes for drought tolerance by PEG (polyethylene glycol) induced drought stress at seedling stage. Legume Research- An International Journal. 44(6): 684-691.

Kiliçaslan, S.C., Yildirim, E., Ekinci, M., Kul, R. (2020). Kuraklık stresinin fasulyede bitki gelipimi, bazı fizyolojik ve biyokimyasal özellikler üzerine etkisi. Erciyes Üniversitesi Fen Bilimleri Enstitüsü Dergisi. 36(2): 264-273.

Lin, C.S., Wu, J.T. (2014). Tolerance of soil algae and cyanobacteria to drought stress. Journal Phycolgy. 50(1): 131-139.

Malua, E., Vassilev, N. (2014). A contribution to set a legal framework for bio-fertilisers. Applied Microbiology and Biotechnology. 98: 6599-6607.

Marulanda, A, Barea, J.M., Azco'n, R. (2009). Stimulation of plant growth and drought tolerance by native microorganisms (AM Fungi and Bacteria) from dry environments: Mechanisms related to bacterial effectiveness. Journal of Plant Growth Regulation. 28: 115-124.

Naveed, M, Hussain, M.B., Zahir, A.Z., Mitter, B., Sessitsch, A. (2014). Drought stress amelioration in wheat through inoculation with Burkholderia phytofirmans strain. Plant Growth Regulation. 73: 121-131.

Osakabe, Y., Osakabe, K., Shinozaki, K., Tran, L.P. (2014). Response of plants to water stress. Frontiers in Plant Science. 5: 86. 
Samancıoğlu, A., Yıldııım, E. (2015). Bitki gelişimini teşvik eden bakteri uygulamalarının bitkilerde kuraklığa toleransı arttırmadaki etkileri, Mustafa Kemal Üniversitesi Ziraat Fakültesi Dergisi. 20(1): 72-79.

Shakir, M.A., Bano, A., Arshad, M. (2012). Rhizosphere bacteria containing ACCdeaminase conferred drought tolerance in wheat grown under semi-arid climate. Soil Environ. 31(1): 108-112.

Sharma, K.D. (2021). Impact of different rhizobial strains on physiological responses and seed yield of mungbean [Vigna radiata (L.) Wilczek] under field conditions. Legume Research-An International Journal. 44(6): 679-683.
Sarma, R.K., Saikia, R. (2004). Alleviation of drought stress in mung bean by strain Pseudomonas aeruginosa GGRJ21 Plant Soil. 377: 111-126.

Vinocur, B., Altman, A. (2005). Recent advances in engineering plant tolerance to Abiotic stress: achievements and limitations. Current Opinion in Biotechnology. 16: 123132.

Wu, D., Wang, G. (2000). Interaction of $\mathrm{CO}_{2}$ enrichment and drought on growth, water use and yield of broad bean (Vicia faba L.). Environmental and Experimental Botany. 43: $131-139$ 